\title{
Ankle-brachial Index and associated factors in individuals with coronary artery disease
}

\author{
Saulo Henrique Salgueiro de Aquino ${ }^{2}$ \\ Isabelle Tenório Melo \\ Carlos Dornels Freire de Souza ${ }^{1}$ \\ (iD) Francisco de Assis Costa
}

\begin{abstract}
1. Núcleo de Estudos em Medicina Social e Preventiva (Nemsp), Departamento de Medicina, Universidade Federal de Alagoas, Campus Arapiraca, Arapiraca, AL, Brasil. 2. Departamento de Medicina, Universidade Federal de Alagoas, Campus Arapiraca, Arapiraca, AL, Brasil.
\end{abstract}

http://dx.doi.org/10.1590/1806-9282.66.4.407

\section{SUMMARY}

OBJECTIVE: Analyzing the association between ABI and the main risk factors for coronary artery disease in coronary patients.

METHODS: Were selected 156 adult patients from a hospital in Maceió, Alagoas. Were evaluated with risk factors age, obesity, hypertension, diabetes mellitus, smoking, and dyslipidemia. PAOD screening was performed by the ankle-brachial index (ABI). The Mann-Whitney, chi-square, and Fisher's exact tests were used. Confidence Interval of $95 \%$ and a significance of $5 \%$.

RESULTS: 67.3\% ( $n=105)$ males, 52.6\% ( $n=82)$ elderly, 23.1\% $(n=34)$ obese, $72.4 \%$ 6\% $(n=113)$ hypertensive, 34.6\% ( $n=54)$ diabetics, 53.2\% ( $n=83)$ smokers, 34.6\% ( $n=54)$ dyslipidemic and 70.5\% ( $n=110)$ with a family history of CAD. 16.7\% ( $n=26)$ of the individuals presented $P A O D$. Three factors were associated with PAOD: age group $\geq 60$ years (OR:3.656; $p=0.005)$, diabetes mellitus (OR:2.625; $p=0.024)$ and hypertension (OR:5.528; $p=0.008)$. No significant difference was observed in the variables smoking, dyslipidemia, family history of CAD, and obesity.

CONCLUSION: The independent risk factors for PAOD were age, diabetes mellitus, and systemic arterial hypertension.

KEYWORDS: Ankle-brachial index. Peripheral vascular diseases. Risk factors.

\section{INTRODUCTION}

Cardiovascular diseases (CVDs) represent a public health problem with high rates of morbidity and mortality, causing 17.9 million deaths per year worldwide'. CVDs include coronary artery disease (CAD), cerebrovascular disease (CBVD), peripheral arterial occlusive disease (PAOD), and aortic atherosclerosis. CAD represents approximately a third of half of the total number of CVD cases ${ }^{2}$. Individuals with CAD are often diagnosed with PAOD, increasing their cardiovascular risk ${ }^{3.4}$.
PAOD is a presentation with manifestations that are often asymptomatic ${ }^{5}$ and can be diagnosed by the ankle-brachial index (ABI). This noninvasive method can provide early therapeutic interventions to reduce mortality and the risk of cardiovascular events ${ }^{6}$.

$\mathrm{ABI}$ is the ratio between the systolic pressure of the ankle and the arm. When there is stenosis or obstruction near the site of pressure measurement, the index value in individuals with PAOD is less than or equal to 0.9. The ABI accuracy detects stenosis greater than

DATE OF SUBMISSION: 05-Nov-2019

DATE OF ACCEPTANCE: 12-Nov-2019

CORRESPONDING AUTHOR: Carlos Dornels Freire de Souza

Departamento de Medicina da Universidade Federal de Alagoas - Av. Manoel Severino Barbosa, S/N, Arapiraca, AL, Brasil - $57309-005$

Tel: +55 87 99622-0698.

E-mail: carlos.freire@arapiraca.ufal.br 
or equal to $50 \%$ of the leg arteries with $75 \%$ sensitivity and $86 \%$ specificity ${ }^{6.7}$.

Considering the magnitude of cardiovascular diseases worldwide, the importance of early identification of high-risk groups, and the need for intervention strategies, this study aimed to analyze the association between the ankle-brachial index and the main risk factors for coronary artery disease in individuals with coronariopathies.

\section{METHODS}

\section{Study design}

This is a cross-sectional observational study.

\section{Time and place of the study}

The study was carried out in the Hospital Foundation of the Sugar and Alcohol Agro-industry of Alagoas, in Maceió - AL, involving patients treated between 2011 and 2014.

\section{Study population}

The study population consisted of 156 patients, based on the following inclusion criteria: i) adult individuals with coronary artery disease (vessel with stenosis diameter $\geq 50 \%$ on cardiac catheterization examination), ii) with an indication for myocardial, percutaneous, or surgical revascularization, iii) asymptomatic or not for peripheral arterial occlusive disease. The following exclusion criteria were adopted: (i) individuals who had peripheral lesions that prevented the measurement of the ABI, such as lesions in a lower limb.

\section{Study variables}

The following variables were analyzed: gender (male and female), age ( $<60$ and $\geq 60)$, body mass index (BMI) (underweight, healthy, overweight, obesity grade I, II, and III), systemic arterial hypertension (SAH) (hypertensive and non-hypertensive), diabetes mellitus (diabetic and non-diabetic), smoking (smokers and nonsmokers), dyslipidemia (dyslipidemic and not dyslipidemic), family history of CAD (FH CAD) (with FH CAD and without FH CAD), and ankle-brachial index $(\mathrm{ABI})(\leq 0.90$ and $>0.90)$.

The BMI was calculated based on the ratio between the body mass $(\mathrm{kg})$ divided by the squared height $\left(\mathrm{m}^{2}\right)$. The cutoff values adopted for assessing the nutritional status were the ones proposed by the WHO: low weight (BMI $<18.5 \mathrm{~kg} / \mathrm{m}^{2}$ ); appropriate weight $\left(18.5 \leq \mathrm{BMI}<25 \mathrm{~kg} / \mathrm{m}^{2}\right)$; overweight $(25 \leq \mathrm{BMI}<30 \mathrm{~kg} /$ $\left.\mathrm{m}^{2}\right)$; grade I obesity $(30.0 \leq \mathrm{BMI}<35 \mathrm{~kg} / \mathrm{m} 2)$; grade II obesity (35.0 $\leq \mathrm{BMI}<40 \mathrm{~kg} / \mathrm{m} 2)$; and grade III obesity (BMI $\left.\geq 40.0 \mathrm{~kg} / \mathrm{m}^{2}\right)$.

The following parameters were considered for the diagnosis of comorbidities and risk factors:

- SAH: arterial pressure $>140 / 90 \mathrm{mmHg}^{8}$;

- DM: fasting glucose $\geq 126 \mathrm{mg} / \mathrm{dl}$ or if already in use insulin or any oral anti-diabetic drug';

- Dyslipidemia: total cholesterol levels $\geq 200 \mathrm{mg} /$ $\mathrm{dl}$ and/or triglycerides $\geq 150 \mathrm{mg} / \mathrm{dl}^{10}$;

- Smoker: an individual who smoked at least one cigarette per day over the previous month;

- FH CAD: self-reported (history of angina, myocardial infarction, coronary angioplasty, myocardial revascularization surgery, or sudden death of father, mother, siblings, and uncles).

\section{Research procedures}

Initially, the individuals were approached and invited to participate in the research. At that moment, we explained the objectives and procedures of the research, and they signed the Informed Consent Form (ICF). In the next step, demographic data were collected using a form designed specifically for this purpose. In the third step, we took measurements of weight and height and measured the systolic pressure in the ankle and arm for the BMI and ABI calculations, respectively.

The measurement of the ABI was taken while the patient was in dorsal decubitus. The systolic blood pressure (SBP) was measured in both the upper limb and lower limb. The measurement of the SBP for calculating the ABI was done with a Microlife BP3AC11PC device. The ABI calculation was obtained by the ratio of the higher systolic blood pressure (SBP) of the posterior tibial artery and/or dorsal artery of the foot, with the higher SBP of the brachial arteries, bilaterally, always considering the lower ABI. The ABI was considered abnormal when $\leq 0.90$.

\section{Statistical treatment}

The data were stored in a Microsoft Excel ${ }^{\circledR}$ database and analyzed using the statistical package SPSS 22.0 (SPSS Inc., Chicago, USA). The normality of the data was initially evaluated using the Kolmogorov-Smirnov test. Continuous variables were described as mean and standard deviation and categorical variables as simple and relative frequencies. The $\mathrm{ABI}$ was categorized into $\leq 0.90$ and $>0.90$ for the association 
analysis. The comparison of the ABI values, based on the presence/absence of risk factors, was performed using the Mann-Whitney U-test. The association was tested by the chi-square or Fisher's exact test, as indicated. We also calculated the odds ratio. We considered a confidence interval of 95\% (95\% CI) and $5 \%$. significance.

\section{Ethical aspects}

The research was approved by the Research Ethics Committee of the Hospital Foundation of the Sugar and Alcohol Agro-industry of Alagoas, Decision No. 001/2011.

\section{RESULTS}

Of the 156 patients studied, the mean age was 60.1 years $(\mathrm{SD} \pm 10.0)$, and $67.3 \%(\mathrm{n}=105)$ were males. Among the risk factors, $41 \%(\mathrm{n}=64)$ were overweight and $23.1 \%(\mathrm{n}=36)$ obese (the average weight was $72.7 \pm 13.8), 72.4 \%$ ( $\mathrm{n}=103)$ were hypertensive, $34.6 \%$ $(\mathrm{n}=54)$ had diabetes mellitus, $53.2 \%(\mathrm{n}=83)$ were smokers, and 34.6\% ( $\mathrm{n}=54)$ had dyslipidemia; 70.5\% $(\mathrm{n}=110)$ had a history of coronary artery disease, and $16.7 \%$ $(\mathrm{n}=26)$ had $\mathrm{ABI} \leq 0.90$ and were, therefore, diagnosed with PAOD (Table 1).

Among the risk factors evaluated, the Mann-Whitney U-test showed that the ABI median values were lower among the elderly, diabetic, and hypertensive patients $(p<0.001)$. No significant difference was observed in the $\mathrm{ABI}$ values regarding the variables smoking, dyslipidemia, family history of CAD, and obesity (Figure 1).

The factors associated with PAOD $(\mathrm{ABI} \leq 0.90)$ were age greater than or equal to 60 years (OR 3.656; 95\% CI 1.38-9.69), presence of diabetes (OR 2.625; 95\% CI 1.116.18), and systemic arterial hypertension (OR 5.528; 95\% CI 1.25-24.51) (Table 2).

\section{DISCUSSION}

The study analyzed the association between ABI and the main risk factors for PAOD. The prevalence of PAOD was $16.7 \%(\mathrm{n}=26)$ and the main factors associated with it were age, diabetes mellitus, and systemic arterial hypertension.

Among the elderly population, the development of PAOD is attributed to changes in the blood vessel walls, interfering in the perfusion of tissues with a reduction of nutrients and oxygen. These changes make the vessels more rigid, resulting in increased peripheral resistance ${ }^{11}$. In a study conducted in Africa involving 483 patients, $68.60 \%$ of those with PAOD were aged over 60 years (OR 2.03; $\mathrm{p}=0.004)^{12}$. Similar results were also observed in Brasil, where the average age of the population with ITB $\leq 0.9$ was 73 years, with a significant association (OR 1.07; $\mathrm{p}<0.001)^{13}$.

The second risk factor for PAOD relates to the presence of diabetes mellitus. The prolonged state of hyperglycemia in diabetes results in damage to the endothelial cells of blood vessels, thrombosis, and lipid deposition, with the additional formation of atherosclerotic plaque ${ }^{14}$. In a national study with 1,610

TABLE 1. SOCIODEMOGRAPHIC CHARACTERIZATION OF INDIVIDUALS WITH CORONARY ARTERY DISEASE (CAD) INCLUDED IN THE STUDY, ALAGOAS, BRASIL, 2019. $(N=156)$

\begin{tabular}{|c|c|c|}
\hline Variable & $n$ & $\%$ \\
\hline \multicolumn{3}{|l|}{ Sex } \\
\hline Male & 105 & 67.3 \\
\hline Female & 51 & 32.7 \\
\hline \multicolumn{3}{|l|}{ Age range } \\
\hline$<60$ & 74 & 47.4 \\
\hline$\geq 60$ & 82 & 52.6 \\
\hline Mean \pm SD & $60.1 \pm 10.0$ & \\
\hline \multicolumn{3}{|c|}{ Body mass index (BMI) } \\
\hline Low weight & 2 & 1.3 \\
\hline Normal & 54 & 34.6 \\
\hline Overweight & 64 & 41.0 \\
\hline Obesity grade 1 & 28 & 18.0 \\
\hline Obesity grade II & 8 & 5.1 \\
\hline Obesity grade III & 0 & 0.0 \\
\hline Mean \pm SD & $72.7 \pm 13.8$ & \\
\hline \multicolumn{3}{|c|}{ Systemic arterial hypertension (SAH) } \\
\hline Hypertensive & 113 & 72.4 \\
\hline Not hypertensive & 43 & 27.6 \\
\hline \multicolumn{3}{|l|}{ Diabetes mellitus } \\
\hline Diabetic & 54 & 34.6 \\
\hline Non-diabetic & 102 & 65.4 \\
\hline \multicolumn{3}{|l|}{ Smoking } \\
\hline Smoker & 83 & 53.2 \\
\hline Non-smoker & 73 & 46.8 \\
\hline \multicolumn{3}{|l|}{ Dyslipidemia } \\
\hline Dyslipidemic & 54 & 34.6 \\
\hline Not dyslipidemic & 102 & 65.4 \\
\hline \multicolumn{3}{|c|}{ Family history of CAD (FH CAD) } \\
\hline With FH CAD & 110 & 70.5 \\
\hline No FHCAD & 46 & 29.5 \\
\hline \multicolumn{3}{|c|}{ Ankle-brachial index $(A B I)$} \\
\hline$\leq 0.90$ & 26 & 16.7 \\
\hline$>0.90$ & 130 & 83.3 \\
\hline
\end{tabular}




\section{FIGURE 1}
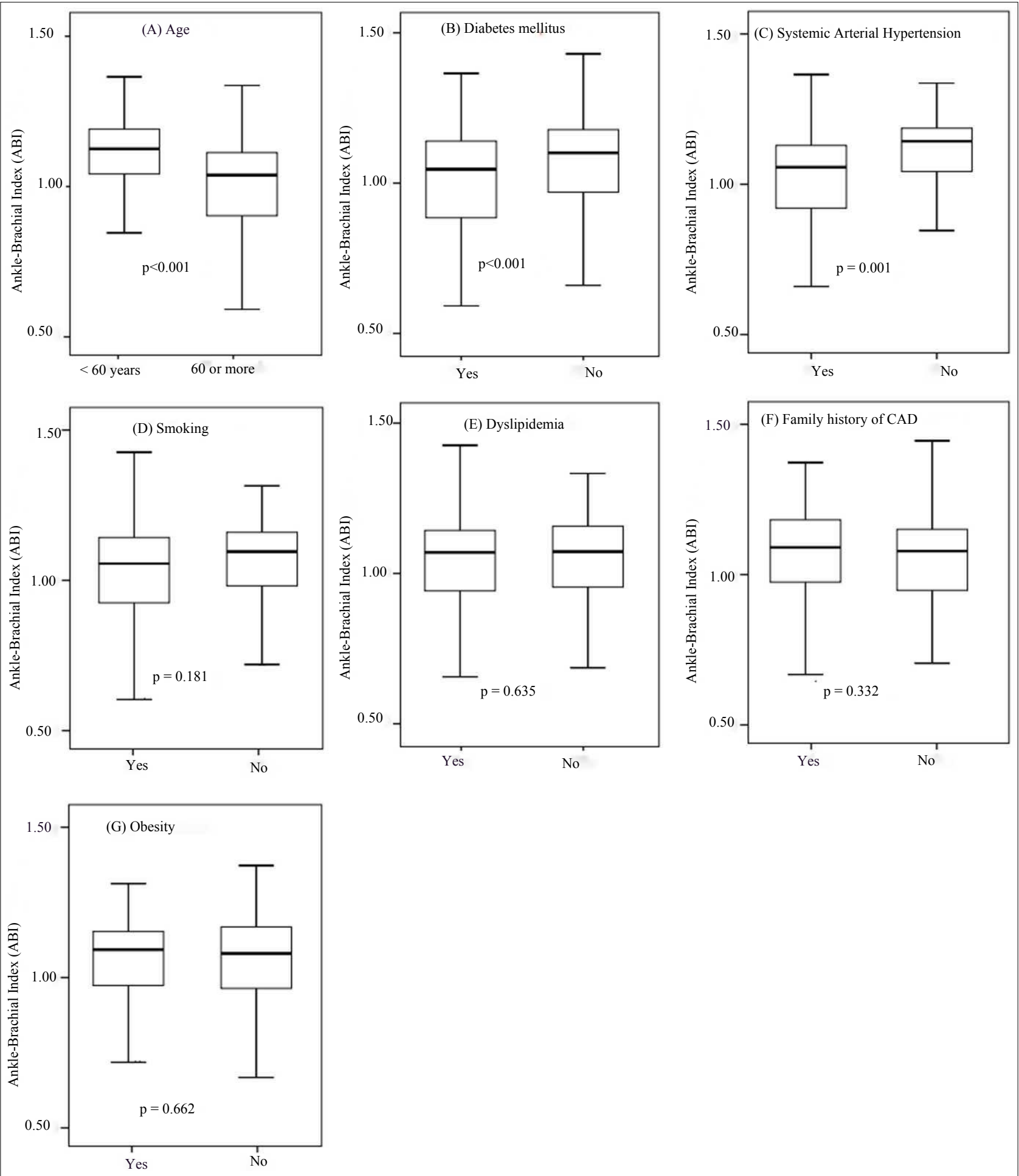

individuals, $41.2 \%$ of patients with PAOD had diabetes (OR 8.77; $\mathrm{p}<0.001)^{15}$. An investigation by Saleh et al. ${ }^{16}$ conducted in the Middle East involving 2,120 patients found diabetes as a factor associated with an increased risk for PAOD, however, with a lower OR than that found in our study (OR 1.827; $\mathrm{p}=0.04$ ).

Hypertension is a third factor associated with a low ABI. It is believed that high-pressure levels result in a dysfunction of blood vessel endothelial cells, increasing the PAOD risk ${ }^{17}$. In a study conducted with 100 patients of a tribe in India, hypertensive individuals presented an odds ratio 3.71 times higher of developing PAOD when compared to normotensive individuals ${ }^{17}$. Similar results were also observed in pre-hypertensive individuals, whose OR was 3.28 , in a comparative study with normotensive individuals ${ }^{18}$.

Although smoking is another risk factor, only $20.5 \%(n=17)$ of smokers presented PAOD $(\mathrm{ABI} \leq 0.90)$, 
with no significant association $(\mathrm{p}=0.173)$. This non-significance also was reported by Sarmento et al. ${ }^{13}$, whose smoking rate was $18.8 \%$. Data from the 2018 Vigitel survey show advances in the reduction of smoking in Brasil: between 2006 and 2017, the proportion of smokers decreased from $15.7 \%$ to $10.1 \%$, and adults who smoke 20 or more cigarettes per day decreased from $4.6 \%$ to $2.6 \%{ }^{19}$.

In a retrospective cohort study conducted in Matsumoto, Japan, with 3,056 patients hospitalized for cardiovascular disease between 2005 and 2012, 41\% of individuals with $\mathrm{ABI} \leq 0.90$ presented dyslipidemia ${ }^{20}$, corroborating our study, in which $38.46 \%$ of individuals with PAOD were dyslipidemic. However, although dyslipidemia is a risk factor, the data did not present statistical significance. It is possible that the size of the POAD population could have influenced the results of the regression.

Most individuals with POAD had a family history of CAD (61.53\%; $n=16)$, but there was no significant association (OR 0.613; CI 0.25-1.47). Similar results were observed in a cross-sectional study with 250 individuals in a district of Izmir, Turkey, in which $49.2 \%$ ( $n=123$ ) of individuals with POAD had a family history of $\mathrm{CAD}^{21}$, and in research performed in Porto Alegre-RS, in which the ratio was $56.6 \%(\mathrm{n}=17)^{22}$.

Although the literature points to obesity as an important risk factor, in our study, only $26.92 \%(\mathrm{n}=7)$ of individuals with PAOD were obese, with no significant association. Similar results were reported in a recent Italian study involving 319 patients, in which the odds ratio was $0.98(\mathrm{p}=0.20)^{23}$, and in the study conducted by Kock et al..$^{24}$ on 93 elderly patients treated in the specialty outpatient clinic of the University of Southern Santa Catarina $(\mathrm{p}=0.551)$.

Even when considering the methodology adopted, the study has limitations, among which stand out the size of the population, time of diagnosis, and severity

TABLE 2. RISK FACTORS FOR PERIPHERAL ARTERIAL OCCLUSIVE DISEASE (PAOD) IN THE POPULATION STUDIED. ALAGOAS, BRASIL, 2019. ( $N=156)$

\begin{tabular}{|c|c|c|c|c|c|}
\hline \multirow[b]{2}{*}{ Variable } & \multicolumn{2}{|c|}{$\mathrm{ABI}$} & \multirow[b]{2}{*}{ p-value ${ }^{1}$} & \multirow[b]{2}{*}{$\mathrm{OR}^{2}$} & \multirow[b]{2}{*}{$\mathrm{Cl} 95 \%$} \\
\hline & $\begin{array}{c}\leq 0.90 \\
n=26(16.7 \%)\end{array}$ & $\begin{array}{c}>0.90 \\
n=130(83.3 \%)\end{array}$ & & & \\
\hline \multicolumn{6}{|l|}{ Sex } \\
\hline Male & $15(14.3)$ & $90(85.7)$ & 0.252 & 0.606 & $0.26-1.43$ \\
\hline Female & $11(21.6)$ & $40(78.4)$ & & & \\
\hline \multicolumn{6}{|l|}{ Age range* } \\
\hline$<60$ & $6(8.1)$ & 68 (91.9) & 0.005 & 3.656 & $1.38-9.69$ \\
\hline$\geq 60$ & $20(24.4)$ & $62(75.6)$ & & & \\
\hline \multicolumn{6}{|c|}{ Diabetes mellitus* } \\
\hline Yes & $14(25.9)$ & $40(74.1)$ & 0.024 & 2.625 & $1.11-6.18$ \\
\hline No & $12(11.8)$ & $90(88.2)$ & & & \\
\hline \multicolumn{6}{|c|}{ Systemic arterial hypertension (SAH)* } \\
\hline Yes & $24(21.2)$ & $89(78.8)$ & 0.008 & 5.528 & $1.25-24.51$ \\
\hline No & $2(4.7)$ & $41(95.3)$ & & & \\
\hline \multicolumn{6}{|l|}{ Smoker } \\
\hline Yes & $17(20.5)$ & $66(79.5)$ & 0.173 & 1.832 & $0.76-4.41$ \\
\hline No & $9(12.3)$ & $64(87.7)$ & & & \\
\hline \multicolumn{6}{|l|}{ Dyslipidemias } \\
\hline Yes & $10(18.5)$ & $44(81.5)$ & 0.652 & 1.222 & $0.51-2.91$ \\
\hline No & $16(15.7)$ & $86(84.3)$ & & & \\
\hline \multicolumn{6}{|c|}{ Family history of CAD } \\
\hline Yes & $16(14.5)$ & $94(85.5)$ & 0.272 & 0.613 & $0.25-1.47$ \\
\hline No & $10(21.7)$ & $36(78.3)$ & & & \\
\hline \multicolumn{6}{|l|}{ Obesity } \\
\hline Yes & $7(19.4)$ & 29 (80.6) & 0.610 & 1.283 & $0.491-3.35$ \\
\hline No & $19(15.8)$ & 101 (84.2) & & & \\
\hline
\end{tabular}


of the cases. In this study, only 26 individuals presented PAOD, which may have compromised the statistical results.

\section{CONCLUSION}

The study showed an association between the presence of PAOD and age, the presence of diabetes mellitus and arterial hypertension. Therefore, the utilization of the ABI to identify and stratify the risks of asymptomatic PAOD in CAD patients is a tool that should be valued in clinical practice. In addition, further studies with a larger population should be conducted to clarify the effects of dyslipidemia, smoking, family history, and obesity on the risk of PAOD.

\section{Contribution of the authors}

Carlos Dornels Freire de Souza, Saulo Henrique Salgueiro de Aquino, Isabelle Tenório Melo, Francisco de Assis Costa: Participated in the development of the concept, planning of the study, data collection and analysis, discussion of the results, scientific writing, as well as in the review and approval of the final version of the work.

\section{RESUMO}

OBJETIVO: Analisar a associação entre o ITB e os principais fatores de risco para doença arterial coronariana em indivíduos coronariopatas.

MÉTODOs: Foram selecionados 156 pacientes adultos de um hospital de Maceió, Alagoas. Foram avaliados como fatores de risco idade, obesidade, hipertensão, diabetes mellitus, tabagismo e dislipidemia. A triagem da DAOP foi realizada pelo índice tornozelo-braquial (ITB). Foram utilizados os testes de Mann-Whitney, qui-quadrado e exato de Fisher. Intervalo de Confiança de 95\% e significância de 5\%.

RESULTADOS: 67,3\% ( $n=105)$ do sexo masculino, 52,6\% ( $n=82$ ) idosos, 23,1\% ( $n=34$ ) obesos, $72,4 \%$ ( $n=113$ ) hipertensos, 34,6\% ( $n=54)$ diabéticos, 53,2\% ( $n=83)$ tabagistas, 34,6\% ( $n=54)$ dislipidêmicos e 70,5\% ( $n=110)$ com história familiar de DAC; 16,7\% ( $n=26)$ dos indivíduos apresentaram DAOP. Três fatores foram associados à DAOP: faixa etária $\geq 60$ anos $(O R: 3,656 ; p=0,005)$, diabetes mellitus $(O R: 2,625 ; p=0,024)$ e $(O R: 5,528 ; p=0,008)$. Não foi observada diferença significativa nas variáveis tabagismo, dislipidemia, história familiar de DAC e obesidade.

CONCLUSÃO: Os fatores de risco independentes para DAOP foram idade, diabetes mellitus e hipertensão arterial sistêmica.

PALAVRAS-CHAVE: Índice tornozelo-braço. Doenças vasculares periféricas. Fatores de risco.

\section{REFERENCES}

1. World Health Organization Global. Cardiovascular disease 2017. [cited 2019 Jul 10]. Available from: https://www.who.int/en/news-room/fact-sheets/ detail/cardiovascular-diseases-(cvds)

2. Wilson PWF. Overview of established risk factors for cardiovascular disease. UpToDate 2018. [cited 2019 Jul 10]. Available from: https://www.uptodate.com/contents/ overview-of-established-risk-factors-for-cardiovascular-disease

3. Sabedotti M, Sarmento-Leite R, Quadros AS. Índice tornozelo-braquial como preditor de doença coronariana significativa em pacientes submetidos à angiografia coronária. Rev Bras Cardiol Invasiva. 2014;22(4):359-63.

4. Neschis DG, Golden MA. Clinical features and diagnosis of lower extremity peripheral artery disease. UpToDate.2018. [cited 2019 Jul 10]. Available from: https://www.uptodate.com/contents/clinical-features-and-diagnosis-of-lower-extremity-peripheral-artery-disease

5. Morley RL, Sharma A, Horsch AD, Hinchliffe RJ. Peripheral artery disease. BMJ. 2018;360:j5842

6. Cornejo Del Rio V, Mostaza J, Lahoz C, Sánchez-Arroyo V, Sabín C, López S, et al; on behalf SPREDIA-2 Group. Prevalence of peripheral artery disease (PAD) and factors associated: an epidemiological analysis from the population-based Screening PRE-diabetes and type 2 DIAbetes (SPREDIA-2) study. PloS One. 2017;12(10):e0186220.

7. Ko SH, Bandyk DF. Interpretation and significance of ankle-brachial systolic pressure index. Semin Vasc Surg. 2013;26(2-3):86-94.

8. Sociedade Brasileira de Cardiologia. VI Diretrizes Brasileiras de Hipertensão. Arq Bras Cardiol. 2010;95(1):1-51.

9. Sociedade Brasileira de Diabetes. Diretrizes da Sociedade Brasileira de Diabetes (2015-2016). São Paulo: Sociedade Brasileira de Diabetes; 2016. [cited 2019 Jul 10]. Available from: https://www.diabetes.org.br/profissionais/ images/docs/DIRETRIZES-SBD-2015-2016.pdf
10. Xavier HT, Izar MC, Faria Neto JR, Assad MH, Rocha VZ, Sposito AC, et al. $\checkmark$ diretriz brasileira de dislipidemias e prevenção da aterosclerose. Arq Bras Cardiol. 2013;101(4 supl. 1):1-20.

11. Maggi DL, Quadros LRDP, Azzolin KO, Goldmeier S. Índice tornozelo-braquial: estratégia de enfermeiras na identificação dos fatores de risco para doença cardiovascular. Rev Esc Enferm USP. 2014;48(2):223-7.

12. Weledji EP, Alemnju NT, Nouediou C. The use of ankle brachial pressure indices in a cohort of black African diabetic patients. Ann Med Surg (Lond). 2018;35:20-4.

13. Sarmento C, Pereira T, Maldonado |, Conde |. Doença arterial periférica e função renal na hipertensão arterial. Arq Bras Cardiol. 2013;100(4):362-7.

14. Hermans MP, Ahn SA, Rousseau MF. The atherogenic dyslipidemia ratio $[\log (T G) / H D L-C]$ is associated with residual vascular risk, beta-cell function loss and microangiopathy in type 2 diabetes females. Lipids Health Dis. 2012;11:132.

15. Alvim RO, Dias FAL, Oliveira CM, Horimoto ARVR, Ulbrich AZ, Krieger JE, et al. Prevalência de doença arterial periférica e fatores de risco associados em uma população rural brasileira: Estudo Corações de Baependi. Int J Cardiovasc Sci. 2018;31(4):405-13.

16. Saleh A, Makhamreh $H$, Ooussoos T, Alawwa I, Alsmady M, Salah ZA, et al. Prevalence of previously unrecognized peripheral arterial disease in patients undergoing coronary angiography. Medicine (Baltimore). 2018;97(29):e11519.

17. Tummala R, Banerjee K, Mahajan K, Ravakhah K, Gupta A. Utility of ankle-brachial index in screening for peripheral arterial disease in rural India: a cross-sectional study and review of literature. Indian Heart J. 2018;70(2):323-5 
18. Rubio-Guerra AF, Garro-Almendaro AK, Lozano-Nuevo JJ, Arana-Pazos KC, Duran-Salgado MB, Morales-López H. Prehypertension is associated with peripheral arterial disease and low ankle-brachial index. Indian Heart J. 2018;70(4):502-5.

19. Brasil. Ministério da Saúde. Secretaria de Vigilância em Saúde. Departamento de Vigilância de Doenças e Agravos não Transmissíveis e Promoção da Saúde. Vigitel Brasil 2017: vigilância de fatores de risco e proteção para doenças crônicas por inquérito telefônico. Brasília: Ministério da Saúde; 2019. p.1-130.

20. Miura T, Minamisawa M, Ueki Y, Abe N, Nishimura H, Hashizume N, et al. Impressive predictive value of ankle-brachial index for very long-term outcomes in patients with cardiovascular disease: IMPACT-ABI study. PloS One. 2017;12(6):e0177609.
21. Vural T, Tan MN, Kartal M, Güldal AD. Detecting peripheral arterial disease in primary care: a population based study. Korean J Fam Med. 2020;41(1):61-7.

22. Petracco AM, Bodanese LC, Porciúncula GF, Teixeira GS, Pellegrini DO Danzmann LC, et al. Avaliação da relação do índice tornozelo-braquial com a gravidade da doença arterial coronária. Int J Cardiovasc Sci. 2018;31(1):47-55.

23. Santoro L, Flex A, Nesci A, Ferraro PM, De Matteis G, Di Giorgio A, et al. Association between peripheral arterial disease and cardiovascular risk factors: role of ultrasonography versus ankle-brachial index. Eur Rev Med Pharmacol Sci. 2018;22(10):3160-5.

24. Kock KS, Silva JBF, Marques JLB. Comparação do índice tornozelo-braquial com parâmetros de rigidez e resistência arterial periférica avaliados por fotopletismografia em idosos. J Vasc Bras. 2019;18:e20180084. 